\title{
Liaoshen Old Industrial Relocation Area Contaminated Soil Treatment Method
}

\author{
Xu-Ming YE ${ }^{1, a}$, Shao-Hui MA ${ }^{1, b}$ \\ ${ }^{1}$ Shenyang University, China \\ ayxm1116888@163.com, ${ }^{\mathrm{b}} \mathrm{ms} 423563509 @ 163 . c o m$
}

Keywords: Liaoshen Area, Old Industrial Relocation Area, Contaminated Soil, Heavy Metal Pollution, Treatment Method.

\begin{abstract}
This document first determine LiaoShen regional old industrial relocation area soil type and the type of soil pollution, on the basis, comparing different foundation soil pollution treatment methods, confirmation has different processing methods according to different requirements.
\end{abstract}

\section{Introduction}

Over the years, unreasonable used of industrial waste emissions, city living garbage, pesticide and fertilizer, made the soil polluted. The surface of polluted soil could not make plant growth, while the pollution of groundwater and agricultural residual contaminants can enter the body through the food chain, to potentially damaging to human health. People paid more and more attention to treatment of contaminated soil. Liaoshen is a heavy industry base in China, the problem of soil pollution is more prominent, this paper studied the Liaoshen old industrial relocation area contaminated soil.

\section{Types and Characteristics of Liaoshen Old Industrial Relocation Area Soil}

\section{Classification and Characteris of Soil}

To carry on processing to the pollution of the soil, we must first understand the types and characteristics of soil.

The soil texture is based on the soil particle composition to the division type. To throw a grain diameter $>2 \mathrm{~mm}$ gravel, have the following division of soil particles:

Tab. 1 Soil particles division

\begin{tabular}{cccc}
\hline Particles & Diameter $(\mathrm{mm})$ & Particles & Diameter $(\mathrm{mm})$ \\
Very coarse sand & $2 \sim 1$ & Very fine sand & $0.10 \sim 0.05$ \\
Coarse sand & $1 \sim 0.5$ & Coarse powder & $0.05 \sim 0.02$ \\
Medium sand & $0.5 \sim 0.25$ & Fine powder & $0.02 \sim 0.002$ \\
Fine sand & $0.25 \sim 0.10$ & clay & $<0.002$ \\
\hline
\end{tabular}

According to the proportion of sand and silt in the soil, soil is generally divided into three categories:

Sandy soil: sand content in $55 \sim 85 \%$ between, soil pores between particles, small little pore, permeable, breathable, easy penetration of polluting substances, pollution of groundwater.

Clay soil: clay particles quantity in $>25 \%$, soil particles pore small, small porous, permeable, permeability is small, polluting substances especially the residual mixed oil in the contaminated soil, pollution was shallow, the chemical reaction between the two pollutants, causing serious pollution problems.

Loam: Volume in $15 \sim 25 \%$ between the soil particles, pore, pore is generally small, waterproof, breathable moderate, pollutant residues and penetration phenomenon generally.

\section{Types and Characteristics of Liaoshen Old Industrial Relocation Area Soil}

LiaoShen old industrial relocation area belongs to the brown loam soil. 
Liaoning region is located in the heart of the southern Songliao Plain, a temperate semi-humid continental climate. The old industrial base in the city center area, which basically brown soil, rubbing thumb thrust into the bar when moist, not broken, dry, hand into the group, when you pick up should not be spread, are brown soil.

Soil characteristics of the old industrial relocation area was slightly acidic, nutrient-rich, chemical lively, light permeable soil permeability, and less permeable lower permeability.

\section{Types and Characteristics of Liaoshen Old Industrial Relocation Area Contaminated Soil}

\section{Types and Characteristics of Contaminated Soil}

Soil pollution is toxic and harmful pollutants produced by human activities into the soil and accumulated to a certain extent, causing deterioration of soil quality, function decreased, adversely affect humans and crops and harm phenomenon. A wide range of soil pollution sources, including industrial sources (industrial "three wastes" emissions of substances), agricultural pollution (fertilizers, pesticides, manure, etc.), living sources (urban and rural domestic wastewater, manure, etc.) and other sources (waste incineration, etc.) and the like.

According to the type of major pollutants to divide, contaminated soil can be divided into the following categories:

(1) Heavy metal pollution. Included with the atmospheric deposition of heavy metals into the soil with heavy metals into the soil of sewage irrigation, solid waste with heavy metals into the soil, a representative of contaminants include arsenic, lead, cadmium.

(2) Persistent organic pollutants. Including organophosphorus pesticides, organochlorine pesticides, oil, polycyclic aromatic hydrocarbons, methane, and other harmful microorganisms. China is the world's largest pesticide use State Department of Agriculture data show that each year about 1.75 million tons of pesticides used in farming forestry production, this figure is the world average of 2.5 to 3 times the amount of pesticide application but only about $30 \%$ effect on the target organism, and the remaining 70 percent were involved in the environment. Our country has produced and widely used pesticide POPs are mainly DDT, hexachlorobenzene, chlordane and mirex, although some pesticides have been banned for many years, but there are still residual soil. At present, a large stock of such contaminated sites.

(3) Organic pollution mainly petroleum, chemical, coking and other contaminated sites. Pollutants are organic solvents, such as benzene, halogenated hydrocarbons represented. Often compounded with other pollutants, such as heavy metals.

(4) Electronic waste. such as contaminated sites. Extensive electronic waste disposal would pose a threat to human health, these venues with heavy metals and pollutants POPs (mainly brominated flame retardants and dioxin-like toxic substances) as the main pollution characteristics.

\section{Types and Characteristics of Liaoshen Old Industrial Relocation Area Contaminated Soil}

Liaoshen area is a heavy industry base in China, in recent years, the old heavy industrial layout start to make adjustments, the heavy industry factory relocation from the city to the outer suburbs, after the relocation of the factory site by waste gas, waste residue containing most of heavy metals pollution, pollution of soil heavy metals, metal containing radioactive substances and other organic pollutants, the main mainly to heavy metal pollution, $\mathrm{Cu}, \mathrm{Zn}, \mathrm{Pb}, \mathrm{Cr}, \mathrm{Cd}$ and $\mathrm{Mn}$ metal particles with adsorbed together, through atmospheric deposition retention in the soil surface layer. Heavy metal particles react with each other, resulting in soil $\mathrm{PH}$ reduce soil acidification, more prompt reaction, and also cause the decomposition of metal microbe enrichment, the natural purification process is slow.

Old industrial relocation is heavy metal pollution, the pollution location is located in the shallow soil layer.

\section{Contaminated Soil Treatment Method}

\section{Classification and Characteristics of Contaminated Soil Treatment Method}

Processing at home and abroad is widely used on the contaminated soil technology plant technology, physical repair technology, physical and chemical joint repair technology. 
Tabl.2 Characteristics of three kinds of repair technique

\begin{tabular}{|c|c|c|c|c|c|}
\hline \multicolumn{2}{|c|}{$\begin{array}{c}\text { Treatment } \\
\text { method }\end{array}$} & $\begin{array}{c}\text { Scope of } \\
\text { application }\end{array}$ & Cost & Effect & Existing problem \\
\hline \multicolumn{2}{|c|}{$\begin{array}{c}\text { Plant } \\
\text { repair } \\
\text { technology }\end{array}$} & $\begin{array}{c}\text { Large area and } \\
\text { don't hurry to } \\
\text { use }\end{array}$ & Plant cost low & $\begin{array}{l}\text { The } \\
\text { environment is } \\
\text { not destroyed, } \\
\text { soil at the same } \\
\text { time the } \\
\text { protection of } \\
\text { atmosphere, } \\
\text { water } \\
\text { ecosystem, } \\
\text { beautify the } \\
\text { natural }\end{array}$ & $\begin{array}{l}\text { Effect of long } \\
\text { processing time, } \\
\text { plant growth is } \\
\text { slow, climate, } \\
\text { vegetation type } \\
\text { is large. More } \\
\text { effective in } \\
\text { shallow soil } \\
\text { remediation, not } \\
\text { deep soil } \\
\text { remediation } \\
\text { effect } \\
\text { satisfaction. }\end{array}$ \\
\hline \multirow[t]{2}{*}{$\begin{array}{l}\text { Physic } \\
\text { al } \\
\text { repair } \\
\text { techno } \\
\text { logy }\end{array}$} & $\begin{array}{l}\text { Heatin } \\
\text { g, guide } \\
\text { air }\end{array}$ & Hurry to use & $\begin{array}{c}\text { The high cost of } \\
\text { equipment }\end{array}$ & Fast & $\begin{array}{l}\text { Pollution } \\
\text { particles } \\
\text { remained } \\
\text { serious,only } \\
\text { suitable for } \\
\text { sandy soil } \\
\end{array}$ \\
\hline & $\begin{array}{l}\text { Replac } \\
\text { ement }\end{array}$ & Hurry to use & The cost is low & Fast & $\begin{array}{l}\text { Not with the } \\
\text { solution to the } \\
\text { problem of soil } \\
\text { pollution }\end{array}$ \\
\hline \multirow{4}{*}{$\begin{array}{l}\text { Physic } \\
\text { al and } \\
\text { chemi } \\
\text { cal } \\
\text { joint } \\
\text { repair } \\
\text { techno } \\
\text { logy }\end{array}$} & $\begin{array}{l}\text { Curing } \\
\text { stabiliz } \\
\text { ation }\end{array}$ & $\begin{array}{l}\text { Pollutants in } \\
\text { shallow soil }\end{array}$ & $\begin{array}{l}\text { In need of } \\
\text { curing agent and } \\
\text { mechanical } \\
\text { equipment, } \\
\text { higher cost of } \\
\text { repair }\end{array}$ & $\begin{array}{c}\text { After curing } \\
\text { may be caused } \\
\text { by the deep soil } \\
\text { and groundwater } \\
\text { pollution }\end{array}$ & $\begin{array}{l}\text { The destruction } \\
\text { of the } \\
\text { environment, } \\
\text { because the cure } \\
\text { stone reversible } \\
\text { need long time } \\
\text { observation }\end{array}$ \\
\hline & $\begin{array}{l}\text { Leachi } \\
\text { ng }\end{array}$ & $\begin{array}{l}\text { The area is } \\
\text { small, the need } \\
\text { for more } \\
\text { thorough repair }\end{array}$ & $\begin{array}{l}\text { Higher cost of } \\
\text { equipment }\end{array}$ & $\begin{array}{l}\text { Pollution } \\
\text { treatment is very } \\
\text { clean }\end{array}$ & $\begin{array}{l}\text { The cost is too } \\
\text { high, the speed } \\
\text { is not quick }\end{array}$ \\
\hline & $\begin{array}{l}\text { Oxidati } \\
\text { on } \\
\text { reducti } \\
\text { on }\end{array}$ & $\begin{array}{l}\text { Groundwater in } \\
\text { need of repair }\end{array}$ & $\begin{array}{l}\text { Redox agent of } \\
\text { high cost }\end{array}$ & $\begin{array}{c}\text { Pollution } \\
\text { treatment } \\
\text { thoroughly, but } \\
\text { have residual } \\
\text { chemicals }\end{array}$ & $\begin{array}{l}\text { The repair time } \\
\text { is longer, the } \\
\text { process is not } \\
\text { controlled }\end{array}$ \\
\hline & $\begin{array}{l}\text { Electr } \\
\text { okinet } \\
\text { ic } \\
\text { remed } \\
\text { iation }\end{array}$ & $\begin{array}{l}\text { Heavy metal } \\
\text { pollution }\end{array}$ & $\begin{array}{l}\text { Low cost of } \\
\text { equipment }\end{array}$ & $\begin{array}{c}\text { Pollution } \\
\text { treatment } \\
\text { quickly clean }\end{array}$ & $\begin{array}{l}\text { Only for heavy } \\
\text { metal pollution, } \\
\text { immature } \\
\text { technology, not } \\
\text { easy to master }\end{array}$ \\
\hline
\end{tabular}


Plant repair technology is on the contaminated soil plant or in the soil into the microbes, through plants and microbes, absorption, decomposition of pollutants accumulation for repair.

The existence form of heavy metals in the soil in all the damage, to make the accumulation of heavy metals in the soil purifying, reducing, fixed function.

Physical repair technology is through the direct or indirect heating soil, or import the hot air in the contaminated soil, so that pollutants separated from soil particles first, and with the steam or hot air export a way of handling, alive by changing soil for repair.

Physical and chemical joint repair technology mainly has several ways, solidification set technology, leaching technology, oxidation reduction technology and electrodynamics repair technology.

Curing stabilization technology is a kind of curing agent added to soil pollution, soil curing agent commonly used such as silicate and zeolite bring some changes to the chemical structure of the soil, and adsorption corresponding chemical pollutants, make its long-term stability in the soil of a way to repair.

Leaching technology is to water or solution of a corresponding processing capacity, and soil mixing, chemistry, physics, reaction, blend in pollution in the solution, and will clear solution has reached to solve pollution repair technology.

Oxidation reduction technology is by investing in the soil chemical oxidant and reducing agent, with pollution particles of soil purification for chemical reactions.

Electrokinetic remediation technology is the composite effect through electrochemical reaction and electrodynamics pollutant enrichment to expel the electrode area, repair mode of centralized treatment or separation.

\section{Liaoshen Old Industrial Relocation Area Contaminated Soil Treatment Method}

According to different requirements, the pollution should be treat different.

When the factory area is large, and need not rush to exploitation, the plant repair technology is best, it's cheap and can used for large area.

And when need rush to exploitation, the electrokinetic remediation technology is best, it's fast and can process a large area.

If the area is small, the leaching technology or replacement technology can be used.

\section{References}

[1]Rosalinda G, John H O, Cari L G, et al. Atmospheric concentrations and deposition of organochlorine pesticides in the US Mid-Atlantic region [J]. Atmospheric Environment, 2005, 39: 2309-2322.

[2]Cui Jian, Du Jizhong, Ma Hongwei, et al. Assessment of organic pollution for surface soil in Shenyang suburbs[J]. Acta ecologica sinica, 2012, 34(24): 7874-7882 (in Chinese with English abstract).

[3]Joan O, Barend L, Alejandr R, et al. Persistant organochlorine compounds in soils and sediments of European high altitude mountain lakes[J]. Chemosphere, 2004, 54: 1549-1561.

[4]Li Xinghong, Wang Wei, Wang Juan, et al. Contamination of soils with organochlorine pesticides in urban parks in Beijing,China[J]. Chemosphere, 2008, 70(9):1660-1668.

[5] Soil classification research group of Nanjing Soil Institute of Chinese Academy of Sciences \& China Soil Classification Research Group. The Retrieval System for China Soil Classification (3rd edition). Hefei: Publishing House of University of Science \& Technology China, 2001: 275. (in Chinese)

[6]Boettinger J L, Howell D, Moore A, Hartemink A E. Digital Soil .Mapping Bridging Research, Environmental Application, and .Operation. Springer-Verlag, 2010: 462.

[7] Soil Geography and Soil Classification Committee of China Soil Science Society. Provisional Draft for China Soil Classification. Hangzhou: Zhejiang People's Press, 1979. (in Chinese) 